American Journal of Cancer Research and Reviews
(AJCRR)

\title{
Humans Papillomavirus (Hpv) Infections in Female Sex Workers in Cote D'ivoire
}

\section{OUATTARA Abdoulaye ${ }^{1}$, YEO Alain ${ }^{2}$, BLAVO-KOUAME E. B. ${ }^{2}$, KOFFI TCHIBEH Franck ${ }^{1}$, SARAKA NGUESSAN Daniel ${ }^{2}$, FAYE-KETTE Hortense ${ }^{2}$ and DOSSO Mireille ${ }^{2}$}

${ }^{1}$ Felix Houphouet Boigny University of Abidjan. Medical Sciences School. Cote d'Ivoire

${ }^{2}$ Pasteur Institute of Cote d'Ivoire Abidjan Cote d'Ivoire

\section{ABSTRACT}

Background: Human Papillomaviruses (HPV) are small virus non-enveloped double-stranded circular DNA. They infect epithelial cells (mucous membranes and skin). Many studies have indicated that having multiple sexual partners may lead to higher HPV transmission. Thus female sex workers (FSWs) may be at greater risk of infection compared to the general population. In female sex workers (FSWs), the risk of HPV infection and cervical cancer is especially high. The aim of this work is to determine the prevalence and the genotypes of Humans Papillomavirus (HPV) that circulate in female sex workers populations in Cote d'Ivoire. Methods: From December 2015 to May 2016, cervical samples from 350 female sex workers were tested for some HR-HPV. HPV DNA was amplified using PGMY09/11 primers which generated 450 base pairs at the L1 region. The samples harboring HPV DNA were genotyped using the multiplex PCR with HPV 16, 18, 31, 33, 35, 45 and 51 primers. Results: The mean age of this population was 32.5 years. On 350 female sex workers HPV DNA was obtained in $51.5 \%$ of the population. A total of $168(94.38 \%)$ specimens harboring HPV DNA were genotypes using multiplex PCR versus $5.61 \%$, which were not genotyped using HPV 16,18, 31, 33, 35, 45 and 51 by multiplex PCR. These 168 strains permit us to identify 204 strains of HPV on whom we have $88.69 \%$ with single infection while 11.30 $\%$ with a multiple infection. Among the multiple infection $36.84 \%$ had respectively double and triple HPV infection and $26.31 \%$ had four HPV infections. HPV genotypes prevalence was the followed: HPV 16 (22.47\%), HPV 18 (26.97\%), HPV 35 (11.23\%), HPV 31 and HPV 33 (7.86\%) respectively and HPV 45 (7.30\%). Any case of HPV genotype 51 was founded. Conclusion: The prevalence of HPV infection in female sex workers is high. The most genotypes which circulate in female sex workers are type 16 and type 18 which are the best known in the world. Keywords: HPV-Prevalence- Genotypes- female sex workers-Côte d'Ivoire

\section{*Correspondence to Author:}

OUATTARA Abdoulaye

Felix Houphouet Boigny University of Abidjan. Medical Sciences School. Cote d'Ivoire

How to cite this article:

OUATTARA Abdoulaye, YEO Alain, BLAVO-KOUAME E. B., KOFFI TCHIBEH Franck, SARAKA NGUESSAN Daniel, FAYE-KETTE Hortense and DOSSO Mireille. Humans Papillomavirus (Hpv) Infections in Female Sex Workers in Cote D'ivoire. American Journal of Cancer Research and Reviews, 2017,1:3.

\section{eSciencePublisher 。}

eSciPub LLC, Houston, TX USA. Website: http://escipub.com/ 


\section{Introduction}

Human Papillomaviruses (HPV) are small virus non-enveloped double-stranded circular DNA. They infect epithelial cells (mucous membranes and skin). There are currently 120 genotypes of HPV that have been identified, including 40 with a specifically genital tropism

Papillomaviruses are classified into two groups according to their oncogenic potential: papillomaviruses with high oncogenic risk (Type 16 and 18) and low risk papillomaviruses (type 6 and 11). HPV at low risk are responsible for benign lesions such as genital warts, papillomas $(2 ; 3 ; 4 ; 5)$ while HPV at high risk are responsible for precancerous lesions, cancers (cervix, vulva).

Today it is very well established by Harald Zur Haussen that infection with specific types of HPV can cause cervical cancer (6). Cote d'Ivoire has a population of 6.37 million women ages 15 years and older who are at risk of developing cervical cancer. Current estimates indicate that every year 1346 women are diagnosed with cervical cancer and 866 die from the disease. Cervical cancer ranks as the 2nd most frequent cancer among women in Cote d'Ivoire and the $2^{\text {nd }}$ most frequent cancer among women between 15 and 44 years of age. Data is not yet available on the HPV burden in the general population of Cote d'Ivoire. However, in Western Africa, the region Cote d'Ivoire belongs to, about $4.3 \%$ of women in the general population are estimated to harbour cervical HPV- 16/18 infection at a given time, and $56.7 \%$ of invasive cervical cancers are attributed to HPVs 16 or 18 . Cancer of the cervix uteri is the 4th most common cancer among women worldwide, with an estimated 527,624 new cases and 265,672 deaths in 2012 (GLOBOCAN). The majority of cases are squamous cell carcinoma followed by adenocarcinomas (7).

About 1,346 new cervical cancer cases are diagnosed annually in Côte d'lvoire (estimations for 2012). Cervical cancer ranks as the 2 nd leading cause of female cancer in Côte
d'Ivoire. Cervical cancer is the 2th most common female cancer in women aged 15 to 44 years in Côte d'Ivoire. About 866 cervical cancer deaths occur annually in Côte d'Ivoire (estimations for 2012). Cervical cancer ranks as the 2 nd leading cause of female cancer deaths in Côte d'Ivoire. Cervical cancer is the 2nd leading cause of cancer deaths in women aged 15 to 44 years in Côte d'Ivoire (7).

Studies have indicated that having multiple sexual partners may lead to higher HPV transmission. Thus female sex workers (FSWs) may be at greater risk of infection compared to the general population. In female sex workers (FSWs), the risk of HPV infection and cervical cancer is especially high. A previous studies have reported that female sex workers had more than twice the probability of having HPV infection than women from the general population and have a prevalence of abnormal pap smears $(8,9)$. In addition, HPV can be transmitted from FSWs to the general population through clients thereby increasing the prevalence of the virus. In Cote d'Ivoire there is a lack of data on the prevalence of HPV in the population of sex workers.

The aim of this work is to determine the prevalence and the genotypes of Humans Papillomavirus (HPV) that circulate in female sex workers populations in Cote d'Ivoire.

\section{Materiel and methods}

Patient Recruitment: This study was carried out at the Red Ruban clinic at Yopougon and Clinique Confiance of Bietry Zone 4 in Abidjan where Men Who have sex with Men and sex workers are taken care and 9 quarters of Abidjan (Abobo, Attecoubé, Adjame, Cocody, Marcory, Koumassi, Port Bouet, Treichville and Yopougon) and the inside of Cote d'Ivoire (Abengourou, Bondoukou, Daloa, Gagnoa, Man and Guiglo) from December 2015 to May 2016.

Methods: After women's consent, they are administered a questionnaire assessing sociodemographic characteristics and sexual habits 
(i.e. age, lifetime number of sexual partners, date of first sex, educational level, condoms use, sex habits, parity and number of pregnancies and place of living and tobacco use and alcohol drink).

Samples collection: The woman once in the gynecological position a non-lubricated speculum is placed to make visible the cervix with the aid of an ordinary light. Samples are taken in the cervix the vagina and stored in virus medium Transport (VTM). The samples were stored at $-20^{\circ} \mathrm{C}$ and then at $-80^{\circ} \mathrm{C}$ at the biobank of Pasteur Institute of Cote d'Ivoire before using for the PCR

PCR detection of HPV: The PCR detection of HPV was performed at Molecular Biology Plateforms of Pasteur Institute of Côte d'Ivoire. PCR detection of HPV was performed according to the procedure of Ausubel and al. (10). This procedure is based on the chloroform phenol extraction method which consists in treating the cell lysate (obtained after enzymatic digestion with proteinase $\mathrm{K}$ ) with a mixture of phenol / chloroform/isoamyl alcohol. Phenol is a deproteinizing agent in which the nucleic acids are not soluble. Chloroform is capable of causing protein denaturation. The anti-foaming activity of isoamyl alcohol will promote the separation of the deproteinized aqueous phase. Recovery of the genomic DNA is achieved following precipitation steps with ethanol and centrifugation steps

HPV DNA extraction protocol: $500 \mu \mathrm{L}$ of endocervical cell samples were centrifuged at $14000 \mathrm{rpm}$ for 15 minutes. The pellet (endocervical cells) obtained after centrifugation is subjected to lysis at $65^{\circ} \mathrm{C}$. for 1 hour by adding $400 \mu$ l of cell lysis buffer (200 $\mu \mathrm{L}$ of Tris- $\mathrm{HCl} \mathrm{pH} 8(0.1 \mathrm{M}), 0.8 \mathrm{ML}$ of EDTA (0.5 M), $20 \mu \mathrm{L}$ of SDS (10\%), $1.5 \mu \mathrm{L}$ of RNAse $(4 \mathrm{mg} / \mathrm{mL}$ ) and $10 \mu \mathrm{L}$ of proteinase $\mathrm{K}(10 \mathrm{mg} /$ $\mathrm{mL})$. After enzymatic digestion, the mixture was centrifuged at $14000 \mathrm{rpm}$ for 5 minutes. Then 2 volumes of phenol / chloroform / isoamyl alcohol (25/24/1) are added to the lysate. The mixture thus obtained is stirred for 2 minutes in a vortex and then centrifuged for $5 \mathrm{~min}$ at $12000 \mathrm{rpm}$. The DNA contained in the aqueous phase is supplemented with 2 volumes of absolute ethanol, $1 / 10$ volume of $3 \mathrm{M} \mathrm{NaCl}$ and precipitated at $-20 \circ \mathrm{C}$. overnight and then centrifuged for $10 \mathrm{~min}$ at $14000 \mathrm{rpm}$. The pellet obtained was washed in $500 \mu \mathrm{L}$ of $70 \%$ ethanol at $14000 \mathrm{rpm}$ for 10 minutes. The precipitate containing the viral DNA is dried with DNA SpeedVac and taken up in $60 \mu \mathrm{l}$ of elution buffer. The DNA extract is subsequently stored at $-20^{\circ} \mathrm{C}$ for further use or at $4^{\circ} \mathrm{C}$ for immediate use.

\section{HPV detection by PGMY11/09 PCR:}

Consensus primers (primarily targeting the HPV $\mathrm{L} 1$ region) were used to detect the viral presence. The PCR was carried out in a reaction medium of $50 \mu \mathrm{l}$ containing $5 \mu \mathrm{L}$ of $5 \mathrm{X}$ colored buffer, $5 \mu \mathrm{L}$ of uncoloured $5 \times$ buffer, 3 $\mu \mathrm{L}$ of $\mathrm{MgCl} 2(25 \mathrm{mM}), 0.5 \mu \mathrm{L}$ of dNTPs (10 $\mu \mathrm{m}), 1 \mu \mathrm{L}$ of each primer $(10 \mu \mathrm{M}), 0.4 \mu \mathrm{L}$ of GoTaq polymerase and $10 \mu \mathrm{L}$ of DNA. The DNA was amplified in a thermal cycler under the following conditions: Initial denaturation at $94^{\circ} \mathrm{C}, 5$ minutes, Denaturation at $94^{\circ} \mathrm{C}, 30$ seconds, Hybridization at $53^{\circ} \mathrm{C}, 30$ seconds $(35$ cycles), Elongation at $72^{\circ} \mathrm{C}, 30$ seconds, Final elongation at $72^{\circ} \mathrm{C}, 7$ minutes. For each serial of cases tested, a negative control containing no matrix DNA was carried out in parallel in order to check the absence of any contamination of the reagents used. A positive control is also tested in parallel with each set of cases. The consensus primers used for HPV detection targeting the conserved $\mathrm{L} 1$ region and producing $450 \mathrm{bp}$ amplicons $(11,12,13)$ are:

Sequence (5 ' 3 ') of the forward primer PGMY11 A: GCACAGGGACATAACAATGG

Sequence (5 ' 3 ') of the reverse primer PGMY09 F: CGTCCCAAAGGAAACTGATC

\section{Separation of DNA fragments by agarose} gel electrophoresis: The electrophoresis apparatus is formed of a Plexiglas plate placed horizontally on a flat support. A comb for forming the wells is aligned parallel to the top of the plate. The assembly is connected by 
electrodes to a current generator. Agarose was prepared at a concentration of $1.5 \%$ with $1 \mathrm{X}$ TBE buffer. The cooled microwave-fused agarose solution was added with $10 \mu \mathrm{L}$ of BET. The solution was then poured onto the plate. After curing the gel, the comb was removed and the cured gel coated with $1 \times 15 \mu \mathrm{L}$ TBE buffer of each DNA sample was deposited in each well. In parallel with the samples, a molecular weight marker is deposited in a well. The migration lasts 20 to 35 minutes and is carried out under a voltage of $110 \mathrm{~V}$.

HPV Genotyping (Tsakiogiannis et al) (14): A method of HPV genotyping by designing seven type-specific primer sets that allow the amplification of strictly conserved regions of $\mathrm{L} 1$ gene in order to identify the HPV genotypes 16 , $18,45,35,33,51$, and 31 and using the human $\beta$-actin gene as internal control. The method was established by designing nine type-specific primer sets that target conserved regions of the L1 gene. In the present study, we developed a method of HPV genotyping by designing nine type-specific primer sets that allow the amplification of strictly conserved regions of $L 1$ gene in order to identify the HPV genotypes 16 , $18,31,33,35,45$, and 51 and using the human $\beta$-actin gene as internal control.

In particular, two distinct primer mixtures were arranged, each containing three L1 typespecific primer sets (Table 1). Moreover, the primer set $b$-actinF/b-actinR, which allows the amplification of the human $\beta$-actin gene, was included in each multiplex PCR primer mixture as an internal control. Specifically, primer mixture I contained primers specific for HPV 16 , 31 and 33; primer mixture II contained primers specific for HPV 18, 35, 45 and 51

Each multiplex PCR primer mixture contained $1 \mu \mathrm{l}$ of each L1 type-specific primer set and $1 \mu \mathrm{mol}$ of the primer pair b-actinF/b-actinR. Each multiplex PCR assay was performed in a final volume of $50 \mu$ l, containing $40 \mu \mathrm{l}$ of the corresponding multiplex PCR primer mixture, $5 \mu \mathrm{l}$ Buffer A, $2 \mathrm{mM} \mathrm{MgCl} 2,1.2 \mathrm{mM}$ dNTPs and $0.5 \mathrm{U}$ of thermostable DNA polymerase. PCR cycling conditions were as follows: an initial denaturation step at $95^{\circ} \mathrm{C}$ for $2 \mathrm{~min}$ and then 40 cycles of $95^{\circ} \mathrm{C}$ for $30 \mathrm{~s}, 58^{\circ} \mathrm{C}$ for $50 \mathrm{~s}$ and $72^{\circ} \mathrm{C}$ for $10 \mathrm{~s}$. The PCR reaction was ended with a 1 -min incubation step at $72^{\circ} \mathrm{C}$.

\section{Results}

The study's population is about 350 sex workers from Abidjan and some cities of Cote d'Ivoire. The minimum age is 17 years and the maximum age is 56 years with an average age of 32.5 years. At the matrimonial level, the population consisted of $70.8 \%$ single women, $0.57 \%$ divorced women, $12.0 \%$ married women, $16.0 \%$ common-law women and 0.85 $\%$ widowed women. The majority of the population came from the city of Abidjan and in particular from the quarter of Port Bouet at $14.57 \%$ followed by Yopougon (12.0\%), Marcory (9.71\%), Koumassi (8.29\%), Adjamé $(8.0 \%)$, Attécoubé $(5.71 \%)$, Treichville and Abobo respectively at $5.43 \%$ and Cocody $(1.14 .0 \%)$. From the country we have Gagnoa at $8.86 \%$ followed by Man (7.14\%), Guiglo $(5.71 \%)$, Bondoukou (2.0\%) and Daloa (1.14 $\%$ ). The majority of the population was not educated $(76.29 \%)$. They are all a sex workers and they all use condoms to work. Any of them used oral contraceptives. $96.28 \%$ of women had below 5 pregnancies and $3.72 \%$ above 5 pregnancies. All of women had below 5 children.

$182(52 \%)$ women had consumed tobacco. 64 $\%$ of the women in this study had their sexual intercourse before the age of 18 years. $57.14 \%$ of women reported working in brothels, $25.43 \%$ in the bar and $17.43 \%$ on sidewalks. $86.28 \%$ of women have less than 10 sexual partners per week.

Of the 350 women who agreed to participate to this study 178 (51.5\%) were positive for HPV DNA. A total of $168(94.38 \%)$ specimens harboring HPV DNA were genotypes using multiplex PCR versus $5.61 \%$, which were not genotyped using HPV 16,18, 31, 33, 35, 45 and 
Table 1: Sequences of HPV type-specific primer sets and the sizes of the respective amplicons (16)

\begin{tabular}{|c|c|c|c|}
\hline Primers & Sequences & Tailles & References \\
\hline \multirow[t]{2}{*}{ HPV 16} & R : 5'GCAATGTAGGTGTATCTCCA3' & \multirow[t]{2}{*}{$395 \mathrm{pb}$} & \multirow{2}{*}{$\begin{array}{l}\text { Tsakogianni } \\
\text { s(2015) }\end{array}$} \\
\hline & F : 5'GTGTGTACTGCAAGCAACAG3' & & \\
\hline \multirow[t]{2}{*}{ HPV 18} & R : 5'CACGCACACGCTTGGCAGGT3' & \multirow[t]{2}{*}{$217 \mathrm{pb}$} & \multirow{2}{*}{$\begin{array}{l}\text { Tsakogianni } \\
\mathrm{s}(2015)\end{array}$} \\
\hline & F : 5’AAGGATGCTGCACCGGCTGA3' & & \\
\hline \multirow[t]{2}{*}{ HPV 31} & R : 5'GTAGTTGCAGGACAACTGAC3' & \multirow[t]{2}{*}{$514 \mathrm{pb}$} & \multirow{2}{*}{$\begin{array}{l}\text { Tsakogiann } \\
\mathrm{s}(2015)\end{array}$} \\
\hline & F : 5’ATGGTGATGTACACAACACC3' & & \\
\hline \multirow[t]{2}{*}{ HPV 33} & F : 5'ATGATAGATGATGTAACGCC3' & \multirow[t]{2}{*}{$455 \mathrm{pb}$} & \multirow{2}{*}{$\begin{array}{l}\text { Tsakogianni } \\
\text { s(2015) }\end{array}$} \\
\hline & R : 5'GCACACTCCATGCGTATCAG3' & & \\
\hline \multirow[t]{2}{*}{ HPV 35} & F : 5'CCCGAGGCAACTGACCTATA3' & \multirow[t]{2}{*}{$230 \mathrm{pb}$} & \multirow{2}{*}{$\begin{array}{l}\text { Tsakogianni } \\
\text { s(2015) }\end{array}$} \\
\hline & R : 5'GGGGCACACTATTCCAAATG3' & & \\
\hline \multirow[t]{2}{*}{ HPV 45} & 2F :5'GCTACAGCTGTTATTACGCAG3' & \multirow[t]{2}{*}{$141 \mathrm{pb}$} & \multirow{2}{*}{$\begin{array}{l}\text { Fontaine } \\
(42)\end{array}$} \\
\hline & 2R : 5'GCAATTGTGCAGGTTTACA3' & & \\
\hline \multirow[t]{3}{*}{ HPV 51} & $2 F:$ & \multirow[t]{3}{*}{$266 \mathrm{pb}$} & \multirow{3}{*}{$\begin{array}{l}\text { Fontaine } \\
(42)\end{array}$} \\
\hline & 5'CCTAAAACCTCAACGCGTGCT3' & & \\
\hline & 2R : 5'TTGTTGTGCATTGCCATTTGC3' & & \\
\hline \multicolumn{3}{|l|}{ Beta globine } & \multirow{3}{*}{$\begin{array}{l}\text { Tsakogianni } \\
\text { s(2015) }\end{array}$} \\
\hline $\mathrm{GH} 20$ & 5' GAA GAG GCA AGG ACAGGTAC3' & \multirow[t]{2}{*}{$268 \mathrm{pb}$} & \\
\hline PCO4 & 5' CAA CTT CAT CCA CGT TCA CC3' & & \\
\hline
\end{tabular}

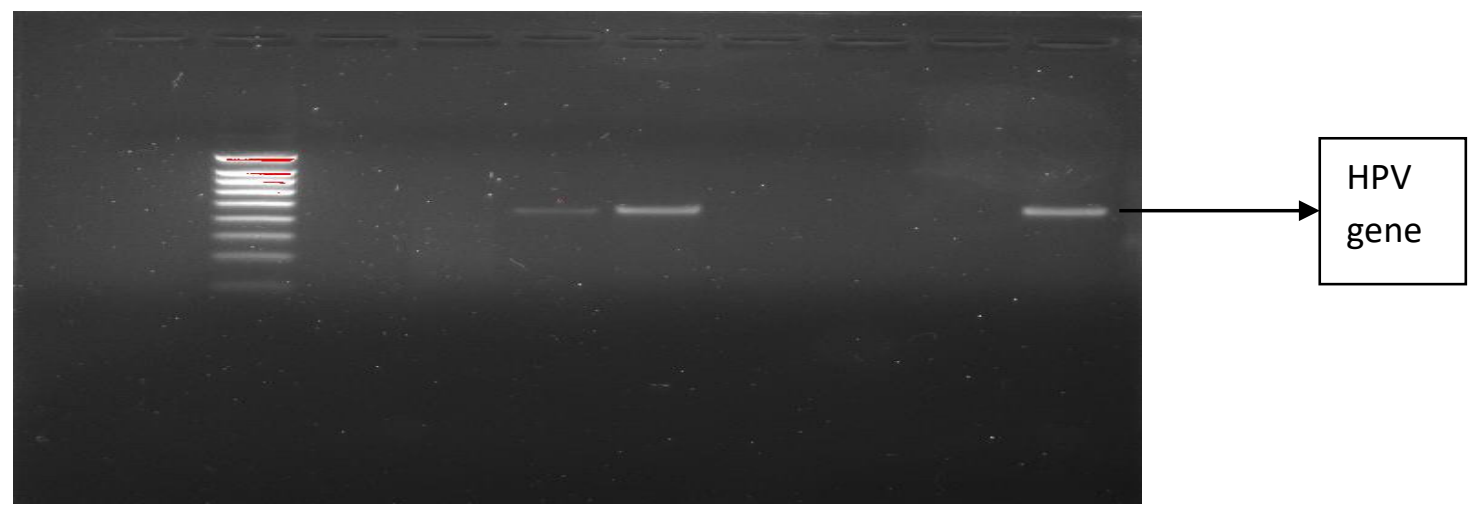

Figure 1: Agarose gel (1,5\%) showing PCR electrophoretic profile using PGMY09/11 oligonucleotide primers for HPV-L1 gene detection corresponding to $\sim 450 \mathrm{pb}$ 


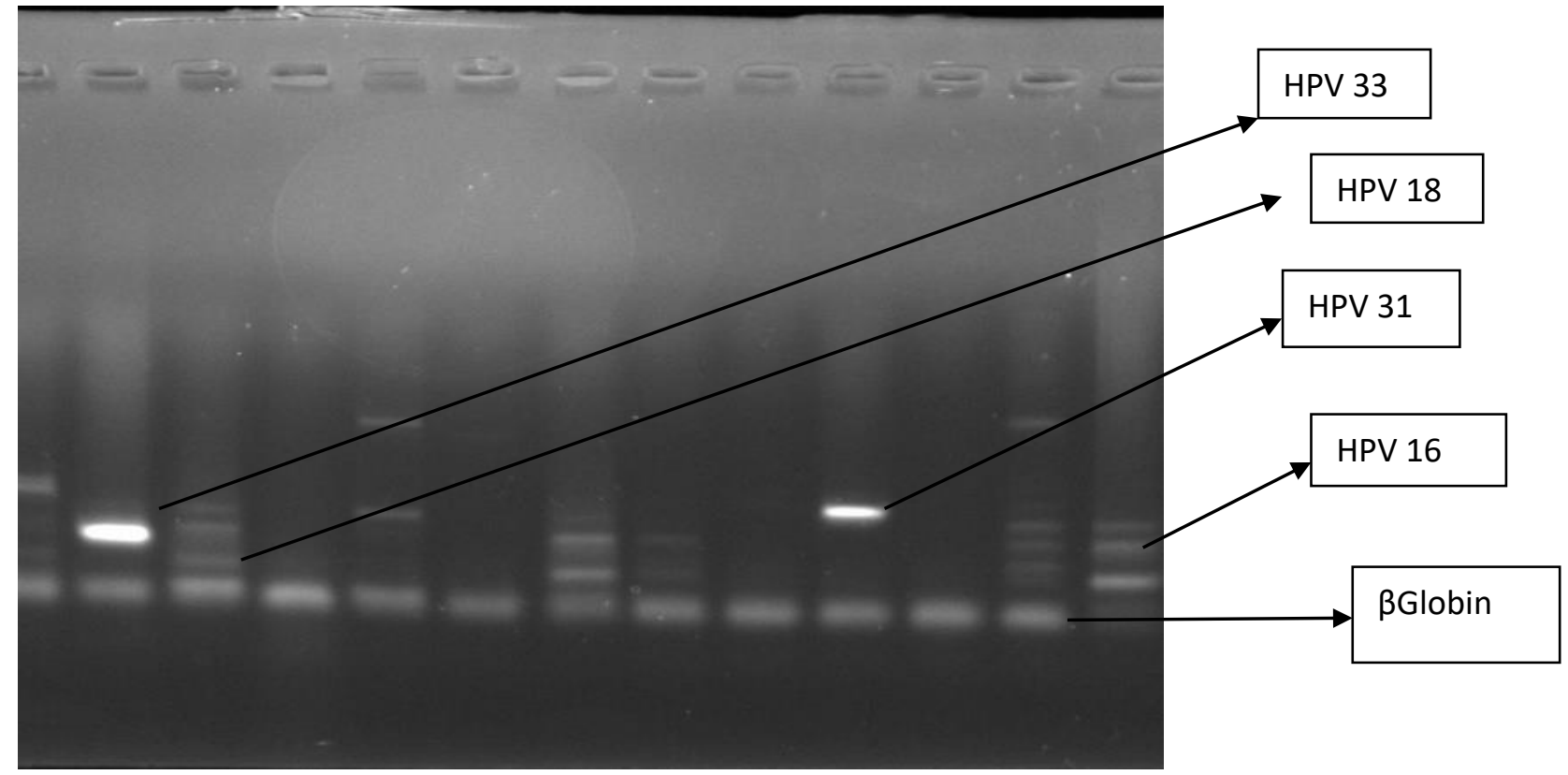

Figure 2: Agarose gel electrophoresis $(1,5 \%)$ of HPV Multiplex reaction-PCR reactions from twelve cervicovaginal samples.

Table 2: Distribution of HPV genotypes founded in this study

\begin{tabular}{llll}
\hline Genotypes & Frequency & Percent & Strains \\
\hline $16,18,35,45$ & 3 & $1,69 \%$ & 12 \\
$16,18,33,45$ & 2 & $1,12 \%$ & 8 \\
$\mathbf{1 6}$ & $\mathbf{4 0}$ & $\mathbf{2 2 , 4 7 \%}$ & $\mathbf{4 0}$ \\
$16,18,45$ & 3 & $1,69 \%$ & 9 \\
16,33, & 1 & $0,56 \%$ & 2 \\
$16,35,33$ & 4 & $2,25 \%$ & 12 \\
16,45 & 1 & $0,56 \%$ & 2 \\
$\mathbf{1 8}$ & $\mathbf{4 8}$ & $\mathbf{2 6 , 9 7 \%}$ & $\mathbf{4 8}$ \\
$\mathbf{1 8 , 3 5}$ & 1 & $0,56 \%$ & 2 \\
18,45 & 2 & $1,12 \%$ & 4 \\
$\mathbf{3 1}$ & $\mathbf{1 4}$ & $\mathbf{7 , 8 6 \%}$ & $\mathbf{1 4}$ \\
$\mathbf{3 1}, 45$ & 1 & $0,56 \%$ & 2 \\
$\mathbf{3 3}$ & $\mathbf{1 4}$ & $\mathbf{7 , 8 6 \%}$ & $\mathbf{1 4}$ \\
$\mathbf{3 3}, 45$ & 1 & $0,56 \%$ & 2 \\
$\mathbf{3 5}$ & $\mathbf{2 0}$ & $\mathbf{1 1 , 2 3 \%}$ & $\mathbf{2 0}$ \\
$\mathbf{4 5}$ & $\mathbf{1 3}$ & $\mathbf{7 , 3 0 \%}$ & $\mathbf{1 3}$ \\
NG & 10 & & \\
\hline TOTAL & $\mathbf{1 7 8}$ & $\mathbf{1 0 0 , 0 0 \%}$ & $\mathbf{2 0 4}$ \\
\hline
\end{tabular}


Table 3: Distribution of HPV according to age class

\begin{tabular}{llll}
\hline Age & HPV + & HPV- & Total \\
\hline$[\mathbf{1 5 , 3 0 [}$ & $16(4.57)$ & $4(1.14)$ & $20(5.43)$ \\
{$[\mathbf{3 0 , 4 5}[$} & $83(23.71)$ & $71(42.42)$ & $54(44.00)$ \\
{$[\mathbf{4 5 , 6 0 [}$} & $79(22.57)$ & $97(12.5)$ & $176(50.28)$ \\
\hline Total & $\mathbf{1 7 8}$ & $\mathbf{1 7 2}$ & $\mathbf{3 5 0}$ \\
\hline
\end{tabular}

Table 4: Characteristics of the study population and HPV + population in Côte d'Ivoire.

\begin{tabular}{|c|c|c|}
\hline & Study population & HPV DNA+ \\
\hline \multicolumn{3}{|l|}{ Age } \\
\hline Mean & 32.51 & 33.29 \\
\hline Min & 17 & 17 \\
\hline Max & 60 & 60 \\
\hline \multicolumn{3}{|l|}{ Marital status } \\
\hline Single & 247 (70.57\%) & $129(72.47 \%)$ \\
\hline Married & $42(12 \%)$ & $19(10.67 \%)$ \\
\hline widowed & 03 (0.85\% & $01(0.56 \%)$ \\
\hline Cohabitant & $57(16.28 \%)$ & $28(15.73 \%)$ \\
\hline Divorcé & $1(0.28 \%)$ & $1(0.58 \%)$ \\
\hline \multicolumn{3}{|l|}{ Place of living } \\
\hline Out of Abidjan & $104(29.71 \%)$ & $45(25.28 \%)$ \\
\hline Abidjan & $246(70.29)$ & $133(74.72 \%)$ \\
\hline Abobo & $19(5.43 \%)$ & $12(6.74 \%)$ \\
\hline Attecoubé & $20(5.71)$ & $10(5.62 \%)$ \\
\hline Adjame & $28(8.00 \%)$ & $10(5.62 \%)$ \\
\hline Yopougon & $42(12.00 \%)$ & $20(11.24 \%)$ \\
\hline Cocody & $04(1.14 \%)$ & $03(1.69 \%)$ \\
\hline Koumassi & $29(8.29 \%)$ & $19(10.67 \%)$ \\
\hline Marcory & $34(9.71)$ & $22(12.36 \%)$ \\
\hline Treichville & $19(5.43 \%)$ & $08(4.49 \%)$ \\
\hline Port Bouet & $51(14.57 \%)$ & $22(12.36 \%)$ \\
\hline \multicolumn{3}{|c|}{ Formal education } \\
\hline Non educated & $267(76.29 \%)$ & $138(77.53 \%)$ \\
\hline Educated & $83(23.71 \%)$ & $40(22.47)$ \\
\hline Primary & $43(12.28 \%)$ & $21(11.80)$ \\
\hline Secondary & $40(11.43 \%)$ & $19(10.67 \%)$ \\
\hline Gestity & & \\
\hline
\end{tabular}




\begin{tabular}{lll}
\hline$<5$ & $337(96.29 \%)$ & $169(94.94 \%)$ \\
$>5$ & $13(3.71 \%)$ & $9(5.06)$
\end{tabular}

Partity

$<5$

$350(100 \%)$

$178(100 \%)$

$>5$

00

00

Oral contraception

Yes

$55(15.76 \%)$

$31(17.42 \%)$

No

294 (84.24\%)

147(82.58)

Condom use

No

00

00

Yes

If Yes already

$350(100 \%)$

178 (100\%)

00

00

Sometimes

00

00

Rarely

00

00

Profession

Sex workers

$350(100 \%)$

$178(100 \%)$

Number of sexual partenaires /week

$<10$

$302(86.28 \%)$

154(86.52\%)

$>10$

$48(13.71 \%)$

$24(13.48 \%)$

Age at first sexual

intercourse

$<18$

$297(84.86 \%)$

156(87.54\%)

$>18$

$53(15.16 \%)$

22(12.36)

Place of work

Home

142(40.57\%)

$90(50.56 \%)$

Bars/night club

$89(24.43 \%)$

$42(23.59 \%)$

Hotels

58(16.57\%)

$13(7.3 \%)$

Streets

$61(17.43 \%)$

$33(18.53 \%)$

Tobacco use

Yes

168 (48\%)

$100(56.18 \%)$

No

$182(52 \%)$

$78(43.82 \%)$

\section{Alcohol drink}

Yes

190(54.28)

115(64.60\%)

No

$160(45.71 \%)$

63(35.39\%) 
51 by multiplex PCR. These 168 strains permit us to identify 204 strains of HPV on whom we have $88.69 \%$ with single infection while 11.30 $\%$ with a multiple infection. Among the multiple infection $36.84 \%$ had respectively double and triple HPV infection and $26.31 \%$ had four HPV infections. HPV genotypes prevalence was the followed: HPV 16 (22.47\%), HPV 18 (26.97\%), HPV 35 (11.23\%), HPV 31 and HPV 33 $(7.86 \%)$ respectively and HPV 45 (7.30\%). Any case of HPV genotype 51 was founded.

\section{Discussion}

The aim of this work was to determine the presence of Papillomavirus DNA in the genital samples of Female sex workers in Cote d'Ivoire. This work permit us to found the rate of $51.05 \%$ of women carrying HPV DNA. This rate seems high and could be explained by several factors. First, the study population consists mainly of sex workers whose number of partners varies from 2 to 17 per week with $15.14 \%$ having 7 partners. Numerous studies have shown that the frequency of ratios is a determining factor in the acquisition of Papillomavirus infections. In addition, some studies have identified an association between non-penetrating sexual behaviors and the detection of HPV in girls. Non-penetrative sexual practices, including handegenital contact and genital sex, have been identified as risk factors for HPV acquisition in heterosexual women $(15,16)$ and in homosexual women who Report having never had a vaginal sex to the penis [17]. Finally the use of condoms was shown to be protective against HPV infection in our study group, which is an issue that has not been well clarified. A meta-analysis of the effect of condom use on the prevention of HPV infection revealed that there was no consistent evidence that condom use reduces the risk of HPV infection (18). Conversely, the study by Tideman et al. (19) showed that a failure to use condoms was significantly associated with HPV infectionThe prevalence of HPV obtained in this study seems close to those reported by many studies in Africa, particularly in Kenya (20) Burkina Fasso $(21,22)$, South Africa $(23,24)$, Tunisia (25), North America specifically in Mexico $(26,27)$, in South America in Peru (28, 29). To these countries we must add those of Asia including South Korea (30, 31), Japan (32) and Cambodia (33). It should be noted that this prevalence of HPV obtained in female sex workers is much higher than that obtained in most European countries $(34,35,36,37)$ and some Asian and Singaporean countries $(38,35,36,37)$. and Bangladesh (39) but also far below some countries such as India (40) and Vietnam (41). These similarities or differences may be due to a variety of factors including environmental factors and population sensitization on HPV infections. This study revealed Papillomavirus genotypes encountered in FSW and whose order was HPV 18 (26.97\%), 16 (22.47\%), HPV HPV 35 (11.23\%), HPV 31 and HPV 33 (7.86\%) respectively. and HPV 45 (7.30\%). Any case of HPV genotype 51 was founded. These different genotypes have also been highlighted by many worldwide in Africa $(20,21,22,23,24)$, Asia $(38,39,40,41)$, Europe $(34,35,36,37)$. ) and in America $(26,27,28,29)$ but not in this order because for most studies it is first the type 16 followed by the type 18 that are the most encountered. Some studies have also found Type 51 in Burkina Faso, Kenya, South Africa $(20,21,22,23,24)$ and Guatemala $(8)$, which was not the case in this study. Regarding the type 45 that has not been identified in some studies as in Burkina Faso in South Africa and Mexico $(21,22,27)$ while this one identified in this study

\section{Conclusion}

The prevalence of HPV infection in female sex workers is high about 50.51. The most genotypes which circulate in female sex workers are type 16 and type 18 which are the best known in the world. However, some highrisk oncogenic genotypes such as types 31 , 33,35 and 45 have been found in significant amounts and should be included in vaccination. 


\section{Limitations}

The main limitation of this study was the small number of women included thus limits the generalization of our data to the whole Ivoirians populations. Then, all positive samples were not confirmed cytologicaly. The DNA extraction was done by the method of phenol chloroform and this kind of methods deemed too long have been abandoned in favor of extraction kit. Despite these limitations, this study shows the necessity the need to continue HPV research in low- income countries.

\section{CONFLICT OF INTERESTS}

The authors have not declared any conflict of interests.

\section{AKNOWLEDGEMENTS}

The authors are extremely grateful to $\mathrm{Dr}$ Tsakiogiannis and Prof Cantarelli for their helpful technical advices as well as to the Pepfar for the material support. Also Pr KacouNgazoa the head of biology molecular platform of Pasteur Institute of Cote d'Ivoire for all the molecular studies done

\section{References}

1. Bernard HU, Burk RD, Chen Z, van Door Slaer K, zurHausen H, de Villiers EM. (2010). Classification of papillomaviruses (PVs) based on $189 \mathrm{PV}$ types and proposal of taxonomic amendments. Virology; 401(1):70-9.

2. Bernard HU. (2005). The clinical importance of the nomenclature, evolution and taxonomy of human papillomaviruses.J Clin Virol. 32 Suppl 1:S1-S6

3. De Villiers EM, Fauquet C, Broker TR et al. (2004). Classification of papillomaviruses. Virol. 324(1):1727.

4. Lacey C.J., Lowndes C.M., Shah K., (2006). Chapter 4: Burden and management of non cancerous HPV-related conditions: HPV 6/11 disease, Vaccine Suppl.3 S35-41.

5. Muñoz N, Bosch FX, De Sanjosé S, Herrero R, Castellsagué X, Shah KV(2003). Epidemiologic classification of human papillomavirus types associated with cervical cancer. $N$ Engl J Med; 348:518-27.

6. Harald zur Haussen. (2009) Papillomaviruses in the causation of human cancers - a brief historical account Virology, Volume 384, Issue 2, Pages 260265
7. Bruni L, Barrionuevo-Rosas L, Albero G, Serrano B, Mena M, Gómez D, Muñoz J, Bosch FX, de Sanjosé S. (2016) ICO Information Centre on HPV and Cancer (HPV Information Centre). Human Papillomavirus and Related Diseases in Côte d'Ivoire. Summary Report 7 October.

8. Valles X, Murga GB, Hernandez G, et al. (2009) High prevalence of human papillomavirus infection in the female population of Guatemala. Int $J$ Cancer; 125: 1161-7.

9. Leung KM, Yeoh GP, Cheung HN, Fong FY, Chan KW. (2013) Prevalence of abnormal Papanicolaou smears in female sex workers in Hong Kong. Hong Kong Med J; 19: 203-6.

10. Ausubel FM, Brent R, Kingston R E., Moore D D. (1999).Short Protocols in Molecular Biology. New York: Greene Pub. Associates and WileyInterscience.

11. Gravitt Gravitt PE, Peyton CL, Alessi TQ (2000). Improved amplification of genital human papillomaviruses. J ClinMicrobiol; 38: 357-61.

12. Gravitt P.E., Kovacic M.B., Herrero R., Schiffman M., Bratti C., Hildesheim A., Morales J., Alfaro M., Sherman M.E., WacholderS., Rodriguez A.C.(2007). Burk R.D., High load for most high risk human papillomavirus genotypes is associated with prevalent cervical cancer precursors but only HPV16 load predicts the development of incident disease, Int. J. Cancer 121: 2787-2793.

13. Gravitt P.E., Kovacic M.B., Herrero R., Schiffman M., Bratti C., Hildesheim A., Morales J., Alfaro M., Sherman M.E., WacholderS., Rodriguez A.C.(2007). Burk R.D., High load for most high risk human papillomavirus genotypes is associated with prevalent cervical cancer precursors but only HPV16 load predicts the development of incident disease, Int. J. Cancer 121: 2787-2793.

14. Tsakogiannis D., V. Diamantidou, E. Toska, Z. Kyriakopoulou, T. G. Dimitriou, I. G. A. Ruether, P. Gortsilas, P. Markoulatos (2015). Multiplex PCR assay for the rapid identification of human papillomavirus genotypes 16 , 18, 45, 35, 66, 33, 51, 58, and 31 in clinical samples. Archives of Virology January 2015, Volume 160, Issue 1, pp 207-214

15. Winer R, Lee S, Hughes J. (2003) Genital human papillomavirus infection: incidence and risk factors in a cohort of female university students. $A m \mathrm{~J}$ Epidemiol;157:218e26

16. Hernandez BY, Wilkens LR, Zhu X, et al. (2008). Transmission of human papillomavirus in heterosexual couples. Emerg Infect Dis;14:888e94.

17. Marrazzo JM, Koutsky LA, Stine KL, et al. (1998) Genital human papillomavirus infection in women who have sex with women. J Infect Dis;178: 16049

18. Manhart LE, Koutsky LA. (2002) Do condoms prevent genital HPV infection, external genital warts, 
or cervical neoplasia? A meta-analysis. Sex Transm Dis; 29: 725-35.

19. Tideman RL, Thompson C, Rose B, et al. (2003) Cervical human papillomavirus infections in commercial sex workers-risk factors and behaviours. Int J STD AIDS; 14: 840-7.

20. Luchters SM, Broeck VD, Chersich MF, et al. (2013) Association of HIV Infection with distribution and viral load of HPV types in Kenya: a survey with 820 female sex workers. BMC Infect Dis 2010; 10: 18 [cited October 24]; 1-10. Available from:http://www.biomedcentral.com/14712334/10/18/

21. Rousseau MN, Costes V, Konate I, et al. (2007). Viral load and genomic integration of HPV 16 in cervical samples from HIV-1-infected and uninfected women in Burkina Faso. J Med Virol 79: 766-70.

22. Didelot-Rousseau MN, Nagot N, Costes-Martineau $\mathrm{V}$, et al. (2006) Human papillomavirus genotype distribution and cervical squamous intraepithelial lesions among high-risk women with and without HIV-1 infection in Burkina Faso. $\mathrm{Br} J$ Cancer 95: 355-62.

23. Marais DJ, Carrara $H$, Ramjee $G$, Kay $P$, Williamson AL (2009). HIV-1 seroconversion promotes rapid changes in cervical human papillomavirus (HPV) prevalence and HPV-16 antibodies in female sex workers. J Med Virol; 81: 203-10

24. Marais DJ, Vardas E, Ramjee G, et al. (2000) The impact of human immunodeficiency virus type 1 status on human papillomavirus (HPV) prevalence and HPV antibodies in serum and cervical secretions. J Infect Dis; 182: 1239-42.

25. Hassen E, Chaieb A, Letaief M, et al. (2003) cervical human papillomavirus infection in Tunisian women. Infection; 31:143-8.

26. Volkow P, Rubi S, Lizano M, et al. (2001) High prevalence of oncogenic human papillomavirus in the genital tract of women with human immunodeficiency virus. Gynecol Oncol; 82: 27-31.

27. Juarez-Figueroa L, Wheeler CM, Uribe-Salas FJ, et al. (2001) Human Papillomavirus: a highly prevalent sexually transmitted disease agent among female sex workers from mexico city. Sex Transm Dis; 28: 125-30.

28. Brown B, Blas MM, Cabral A, et al. (2012) Human papillomavirus prevalence, cervical abnormalities and risk factors among female sex workers in Lima, Peru. Int J STD AIDS; 23: 242-7.

29. Montano SM, Hsieh EJ, Calderon M, et al. (2011) Human papillomavirus infection in female sex workers in Lima, Peru. Sex Transm Infect; 87: 81-2.
30. Yun H, Park J, Choi I, Kee M, Choi B, Kim S. (2008) Prevalence of human papillomavirus and herpes simplex virus type 2 infection in Korean commercial sex workers. J Microbiol Biotechnol; 18: 350-4.

31. Choi BS, Kim SS, Yun H, Jang DH, Lee JS. (2007) Distinctive distribution of HPV16 E6 D25E and E7 N29S intratypic Asian variants in Korean commercial sex workers. J Med Virol 79: 426-30.

32. Matsushita K, Sasagaqa $\mathrm{T}$, Miyashita $\mathrm{M}$, et al. (2011) Oral and cervical human papillomavirus infection among female sex workers in Japan. Jpn $J$ Infect Dis; 64: 34-9.

33. Couture MC, Page K, Stein ES, et al. Cervical (2012). Human papillomavirus infection among young women engaged in sex work in Phnom Penh, Cambodia: prevalence, genotypes, risk factors and association with HIV infection BMC Infect Dis; 12: 166. [cited 2013 October 24]; 1-11. Available from: http://www.biomedcentral.com/1471-2334/12/166

34. Canadas M, Bosch FX, Junquera ML, et al. (2004) Concordance of prevalence of human papillomavirus DNA in anogenital and oral infections in a high-risk population. J Clin Microbiol; 42: 13302.

35. Mak R, Van Renterghem L, Cuvelier C. (2004) Cervical smears and human papillomavirus typing in sex workers. Sex Transm Infect; 80: 118-20.

36. Ortiz M, Torres M, Munoz L, et al. (2006) Oncogenic human papillomavirus (HPV) type distribution and HPV type 16 E6 variants in two Spanish population groups with different levels of HPV infection risk. J Clin Microbiol; 44: 1428-34.

37. Shikova E, Todorova I, Ganchev G, KousevaDragneva V, Kalasheva-Zaimova P. (2011). Prevalence of human papillomavirus infection among female sex workers in Bulgaria. Int $J S T D$ AIDS. 22: 278-80.

38. Chan R, Khoo L, Hong HT, et al (2001). A comparative study of cervical cytology, coloscopy and PCR for HPV in female sex workers in Singapore. Int J STD AIDS 12: 159-63.

39. Huq M, Nahar S, Alam A, Imam H, Rahman M. (2012) The prevalence of selected high-risk human papillomavirus infections among female sex workers in Dhaka, Bangladesh. Int J STD AIDS; 23: 151-

40. Ghosh I, Ghosh P, Bharti AC, Mandal R, Biswas J, Basu P. (2012) Prevalence of human Papillomavirus and co-existent sexually transmitted infections among female sex workers, men having sex with men and injectable drug abusers from eastern India. Asian Pac J Cancer Prev; 13930: 799-802 
41. Hernandez BY, Vu Nguyen T. (2008) Cervical human papillomavirus infection among female sex workers in southern Vietnam. Infect Agent Cancer 3: 7.

42. Weyn C, Boulenouar S, Mathys V, Vanhoolandt J, Bernis A, Fontaine V (2015) Detection of human papillomavirus types 45 and 51 by type-specific polymerase chain reaction. Short communication. Journal of Virological Methods 146: 405-408.

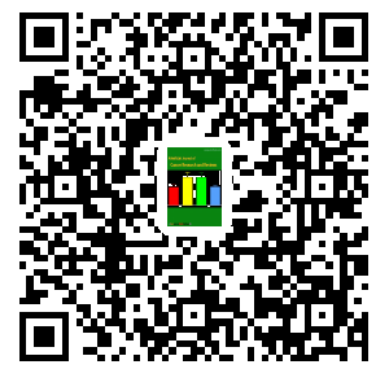

